\title{
THE STABILITY OF PRIDERITE, LINDSLEYITE-MATHIASITE AND YIMENGITE- HAWTHORNEITE UNDER LOWER CONTINENTAL LITHOSPHERE CONDITIONS: EXPERIMENTS AT 35 TO 50 KBAR
}

\author{
Foley; ${ }^{(1)}$ S.F.; Hoefer, ${ }^{(2)}$ H.; and Brey, ${ }^{(2)}$ G.P. \\ (1)Mineralogisch-Petrologisches Institut, Universität Göttingen, Goldschmidtstrasse 1, 3400 Göttingen, Germany; \\ (2)Max-Planck-Institut für Chemie, Abt. Kosmochemie, Saartrasse 23, 6500 Mainz, Germany
}

Members of the alkali-titanate mineral series Priderite, LindsleyiteMathiasite and Yimengite-Hawthorneite are potentially important reservoirs for silicate-incompatible elements in the source regions of alkaline magmas including kimberlites and lamproites. Particularly LIMA and YIHA can contain considerable abundances of Sr, LREE and HFSE (Haggerty et al. 1983).

Priderite occurs as a late-crystallizing phase in lamproites and is also known from nodules which are interpreted to represent the highpressure crystallization products of lamproitic magmas. LIMA and YIHA occur in "metasomatised" xenoliths where an incompatible element-rich agent has infused a depleted peridotite wall-rock; the Cr-rich nature of spinels and other titanates in depleted peridotite appears to be crucial to the genesis of these minerals (Jones et al., 1982; Haggerty, 1983).

IIMA, YIHA and priderite have all been found as inclusions in diamonds from southern Africa, Siberia or Western Australia, indicating their possible stability in the source regions of kimberlites and

lamproites. Mineral associations of YIHA have been used to suggest that hawthorneite in southern Africa crystallized at 70-100 km depth (Haggerty et al., 1989), whereas yimengites from Venezuela originate as deep as 150 $\mathrm{km}$ (Nixon and Condliffe, 1989). Only preliminary high-pressure experiments investigating the stability of these minerals have been undertaken, and to a.maximum pressure of only $30 \mathrm{Kbar}$ (Dubeau and Edgar, 1985).

Experiments investigating the stability of these minerals at 35 to 50 Kbar and temperatures of $1200-1550^{\circ} \mathrm{C}$ are reported here. The IIMA $\left(\mathrm{AM}_{21} \mathrm{O}_{38}\right)$ and YIHA $\left(\mathrm{AM}_{12} \mathrm{O}_{19}\right)$ compositions investigated are simplified with respect to natural minerals whilst retaining enough of their characteristics to allow application of the results to the Earth's mantle. The compositions were simplified in the following ways: (i) only $\mathrm{K}$ and $\mathrm{Ba}$ were included in the $\mathrm{A}-$ site, omitting such elements as $\mathrm{Ca}, \mathrm{Sr}$ and LREE; (ii) for LIMA, the M-site contains > 12 cations $\mathrm{Ti}$, and $\mathrm{Cr}$ is the second most abundant cation, as in natural minerals; (iii) no cations with valency 5 are included. The formulae of the compositions investigated, in which all Fe is trivalent, are;

$\begin{array}{lll}\text { IIMA : } & \left(\mathrm{K}_{0.5} \mathrm{Ba}_{0.5}\right) & \left(\mathrm{Ti}_{13} \mathrm{Cr}_{3.5} \mathrm{Fe}_{1} \mathrm{Zr}_{1} \mathrm{Mg}_{2.5}\right) \mathrm{O}_{38} \\ \underline{\text { YIHA }:} & \left(\mathrm{K}_{0.5} \mathrm{Ba}_{0.5}\right) & \left(\mathrm{Ti}_{3} \mathrm{Cr}_{4.5} \mathrm{Fe}_{2} \mathrm{Mg}_{2.5}\right) \mathrm{O}_{19}\end{array}$

All experiments were synthesis runs using starting mixtures made up of oxides ( $\mathrm{Ti}, \mathrm{Cr}, \mathrm{Zr}, \mathrm{Mg}$ and $\mathrm{Fe}$ ), titanates $\left(\mathrm{K}_{2} \mathrm{Ti}_{2} \mathrm{O}_{5}\right.$ and $\left.\mathrm{BaTiO}_{3}\right)$ and/or $\mathrm{BaFe}_{2} \mathrm{O}_{4}$. Since $\mathrm{K}_{2} \mathrm{CO}_{3}$ and $\mathrm{BaCO}_{3}$ were used as sources for potassium and barium, the titanates and ferrite were crystallized at 1 atm to avoid inclusion of $\mathrm{CO}_{2}$ in the high pressure experiments.

Experiments were run in a high-temperature-calibrated belt apparatus at the Max-Planck-Institut für Chemie in Mainz, with pressure controlled automatically to within 300 bar. Samples were sealed in Pt capsules, and natural polycrystalline $\mathrm{CaF}_{2}$ was used as the pressure-transmitting medium. Run times varied from 4.72 hours for priderite at $50 \mathrm{Kbar}$ and $1550^{\circ} \mathrm{C}$ to 113 hours for YIHA at $50 \mathrm{Kbar}$ and $1200^{\circ} \mathrm{C}$.

Priderite was found to be stable at $50 \mathrm{Kbar}$ and 1200 to $1500^{\circ} \mathrm{C}$ (runs were made at $100^{\circ} \mathrm{C}$ intervals); only at $1500^{\circ} \mathrm{C}$ was appreciable melt present. Lower temperature runs with small amounts of glass $(<2 \%)$ are interpreted to 
represent stable priderite whose composition is slightly removed from the arbitrarily chosen bulk charge composition. Two mixes differing in $\mathrm{K} / \mathrm{Ba}$ and $\mathrm{Ti} / \mathrm{Fe}$ were used for priderite in runs with Fe present as ferric iron; $\mathrm{K} / \mathrm{Ba}$ ratios were 1.5 and 3.0 and $\mathrm{Ti} / \mathrm{Fe}$ ratios 3.89 and 6.75 respectively. These showed that the stable high-pressure priderite has high $\mathrm{K} / \mathrm{Ba}$ of between 3.85 and 4.05 even when $\mathrm{K} / \mathrm{Ba}$ of the starting $\mathrm{mix}$ is only 1.5 . Priderite forms large crystals (50-100/1) which are deeply coloured and pleochroic between purplish grey and greenish brown.

LIMA crystallized to form bright green crystals generally $30-50 \mu$ in size under all conditions studied ( $\left.35 \mathrm{Kbar}, 1300^{\circ} \mathrm{C} ; 50 \mathrm{Kbar}, 1200-1350^{\circ} \mathrm{C}\right)$. IIMA formed a single phase with composition only very slightly different from the starting material, as can be seen by comparing the microprobe analysis of a run product in the table with the formula for the starting mix given above. The largest difference is the higher $\mathrm{K} / \mathrm{Ba}$ of the stable mineral.

Microprobe analyses and structural formulae of high-pressure phases

\begin{tabular}{|c|c|c|c|}
\hline & IIMA & Yimengite & Hawthorneite \\
\hline & $50 \mathrm{Kbar}, 1350^{\circ} \mathrm{C}$ & $50 \mathrm{Kbar}, 1350^{\circ} \mathrm{C}$ & $50 \mathrm{Kbar}, 1350^{\circ} \mathrm{C}$ \\
\hline $\mathrm{TiO}_{2}$ & 60.94 & 25.23 & 24.31 \\
\hline $\mathrm{Cr}_{2} \mathrm{O}_{3}$ & 15.49 & 36.32 & 35.67 \\
\hline $\mathrm{Fe}_{2} \mathrm{O}_{3}$ & 4.78 & 14.09 & 17.00 \\
\hline MgO & 6.09 & 16.82 & 10.43 \\
\hline $\mathrm{ZrO}_{2}$ & 7.74 & 0.00 & 0.00 \\
\hline $\mathrm{K}_{2} \mathrm{O}$ & 1.47 & 7.24 & 1.78 \\
\hline $\mathrm{BaO}$ & 3.49 & 0.29 & 10.80 \\
\hline \multicolumn{4}{|l|}{ Cations } \\
\hline $\mathrm{Ti}$ & 12.962 & 2.845 & 2.920 \\
\hline $\mathrm{Cr}$ & 3.464 & 4.306 & 4.504 \\
\hline $\mathrm{Fe}$ & 1.018 & 1.590 & 2.043 \\
\hline $\mathrm{Mg}$ & 2.568 & 3.758 & 2.482 \\
\hline $\mathrm{Zr}$ & 1.067 & 0.000 & 0.000 \\
\hline $\mathbf{K}$ & 0.532 & 1.386 & 0.364 \\
\hline $\mathrm{Ba}$ & 0.387 & 0.017 & 0.676 \\
\hline oxygens & 38 & 19 & 19 \\
\hline A-total & 0.92 & 1.40 & 1.04 \\
\hline M-total & 21.08 & 12.50 & 11.95 \\
\hline
\end{tabular}

YIHA was investigated at $43 \mathrm{Kbar}, 1150-1250^{\circ} \mathrm{C}$ and 50 Kbar, $1200-$ $1350^{\circ} \mathrm{C}$. Under all these conditions yimengite and hawthorneite form separate phases, indicating the presence of a solvus between potassium- and bariumrich end-members. Yimengite forms large crystals $(50-100 \mu)$, whereas hawthorneite crystals are extremely small $(<10 \mu)$. Atomic ratios $(\mathrm{K} / \mathrm{Ba})$ on the A-site for these coexisting phases are $>45: 1$ for yimengite and approximately 1:2 for the hawthorneitic crystals. In spite of the yimengite being closer to the end-member composition in terms of $\mathrm{K} / \mathrm{Ba}$, the 
stoichiometry of the hawthorneites is much closer to the ideal formula $\mathrm{AM}_{12} \mathrm{O}_{19}$ (see table). The yimengites show consistent excess in cation totals on both A-site and M-site, although the cation charge total equals 38.004 with all $\mathrm{Fe}$ as $\mathrm{Fe}^{3+}$; the $\mathrm{AM}_{12} \mathrm{O}_{19}$ "magnetoplumbite" structure was confirmed by $x$-ray diffraction. Large excesses of cations are known from natural LIMA crystals (Haggerty et al., 1983), but not from natural YIHA.

In separate experiments, end-members compositions of lindsleyite, mathiasite, yimengite and hawthorneite have been successfully synthesized at $50 \mathrm{Kbar}$ and $1300^{\circ} \mathrm{C}$. Crystallographic studies have confirmed the hawthorneite to be space group $\mathrm{P}_{3}$; hexagonal unit cell parameters are (a) 5.862 (2) $\mathrm{A}$ and (c) 22.91 (2) A in comparison to the calculated values of (a) 5.871 (2) \& and (c) 23.06 (2) \& of Haggerty et al. (1989). Structural refinements of the other end-member phases are in progress; preliminary Xray data are similar to published patterns, confirming the presence of the end-member minerals.

Both K-rich and Ba-rich natural examples of the yimengitehawthorneite series are known from xenoliths in China and southern Africa respectively (Haggerty et al., 1989). Nixon and Condliffe (1989) have reported natural yimengites from Venezuela with up to 198 of A-sites occupied by $\mathrm{Ba}$ : this falls within the solvus region defined by the present experiments, indicating either that different conditions applied (e.g. higher temperatures leading to closure of the solvus) or that the solvus is more restricted in natural systems. Intermediate members of this series with $\mathrm{K} / \mathrm{Ba}$ close to unity have not yet been reported, which may be due to the solvus, although exsolved examples are also lacking.

A second starting mix of priderite in which all iron is present in the ferrous state has been briefly studied. This modification was prompted by the cation totals of priderite inclusions in diamonds from Western Australia (Jaques et al. 1989); these are much closer to the expected stoichiometry if $\mathrm{Fe}$ is ferrous instead of ferric as often assumed. Also, it is unlikely that all iron could be present in the ferric state at $\mathrm{fO}_{2} \mathrm{low}^{\mathrm{O}}$ enough to allow diamond stability. In these extra experiments, a graphite sleeve was included inside the pt capsule to prevent excessive alloying of Pt with $\mathrm{Fe}$ in the sample. Iron was included in the starting $\mathrm{mix}$ as a mixture of metallic $\mathrm{Fe}, \mathrm{Fe}_{2} \mathrm{O}_{3}$ and $\mathrm{BaFe}_{2} \mathrm{O}_{4}$. This priderite has been successfully synthesized at $35 \mathrm{Kbar}, 1200^{\circ} \mathrm{C}$ and $50 \mathrm{Kbar}, 1200-1300^{\circ} \mathrm{C}$.

These experiments confirm the stability of priderite, IIMA, yimengite and hawthorneite at pressures corresponding to those of the diamond stability field, and thus underline their possible importance as reservoirs for silicate-incompatible elements in the source regions of kimberlites and/or olivine lamproites. Petrographic and mineral chemical studies, however, suggest that these minerals may be restricted to reaction zones between metasomatic enriching agents and depleted peridotite containing Crrich spinels (Jones et al., 1982; Haggerty 1983). Further experiments testing the stability of these alkali-titanates in assemblages such as Cr$\mathrm{spn}+\mathrm{ol}+\mathrm{op} \mathrm{p}+\mathrm{phl}$ are needed to closely delineate the assemblages with which alkali-titanates could coexist in the mantle.

Dubeau, M.L. and Edgar, A.D. (1985) Min. Mag. 49, 603-606

Haggerty, S.E. (1983) Geochim. Cosmochim. Acta 47, 1833-1854

Haggerty, S.E., Smyth, J.R., Erlank, A.J., Rickard, R.S. and Danchin, R.V. (1983) Am. MineraI. 68, 494-505

Haggerty, S.E., Grey, I.E., Madsen, I.C., Criddle, A.J., Stanley, C.J. and Erlank, A.J. (1989) Am. Mineral. 74, 668-675

Jaques, A.L., Hall, A.E., Sheraton, J.W., Smith, C.B., Sun, S-S., Drew, R.M., Foudoulis, C. and Ellingsen, K. (1989) In: Kimberlites and related rocks Vol.2 (eds. S.Y. O'Reilly, R.V.Danchin and A.J.A.Janse) 966-989, Blackwell, Melbourne.

Jones, A.P., Smith, J.V. and Dawson, J.B. (1982) J.Geol. 90, 435-453

Nixon, P.H. and Condliffe, E. (1989) Min. Mag. 53, 305-309 